\title{
COMPARISON OF PSYCHOMOTOR DEVELOPMENT SCREENING TEST AND CLINICAL ASSESSMENT OF PSYCHOMOTOR DEVELOPMENT
}

\author{
Goranka Radmilović ${ }^{1}$, Valentina Matijević ${ }^{2}$ and Iris Zavoreo $^{3}$
}

\author{
${ }^{1}$ Special Hospital for Medical Rehabilitation, Daruvarske Toplice, Daruvar; \\ ${ }^{2}$ Clinical Department of Rheumatology, Physical Medicine and Rehabilitation, \\ ${ }^{3}$ Clinical Department of Neurology, Sestre milosrdnice University Hospital Center, Zagreb, Croatia
}

\begin{abstract}
SUMMARY - Numerous adverse factors are acting in the prenatal, perinatal and postnatal period of life and may be the cause of later mild or severe deviations from normal psychomotor development. Therefore, it is crucial to identify infants with neurological risk factors and infants that already have a delay from orderly development, in order to immediately initiate the rehabilitation process. The aim of this study was to determine whether there is difference in the assessment of psychomotor development in neurological risk children based on the psychomotor development test (Croatian, Razvoj psibomotorike, RPM test) and clinical evaluation of neuromotor development. RPM test is designed for rough estimate of psychomotor development in children in the first two years of life. The study included 15 full term children (8 male and 7 female) with clinical diagnosis of mild paraparesis and mild deviation from normal psychological and social development, and 15 full term children (8 male and 7 female) without neurological risk factors and deviations from normal psychomotor development, all at the age of 12-24 months. Of the 15 children diagnosed with mild paraparesis, none had delayed psychomotor development, $6.7 \%$ had suspect development and $93.3 \%$ had normal development on RPM test. All children in the control group had normal development on RPM test. According to the results, the RPM test is not sensitive enough to detect mild neurodevelopmental disorders.
\end{abstract}

Key words: Child; Developmental disabilities; Psychomotor disorders; Rehabilitation

\section{Introduction}

Child psychomotor development and factors affecting it today are the subject of interest of many studies, in particular by the experts involved in the protection and improvement of children's health. During the past 15 years, studies were mostly based on the preschool children, schoolchildren and adolescents, or on predicting mental and motor development of infants according to the milestones, or on the evaluation

Correspondence to: Assist. Prof. Valentina Matijevic, MD, PhD, Clinical Department of Rheumatology, Physical Medicine and Rehabilitation, Sestre milosrdnice University Hospital Center, Vinogradska c. 29, HR-10000 Zagreb, Croatia

E-mail: valentina.matijevic@gmail.com

Received July 1,2016, accepted August 8, 2016 of the quality of spontaneous motility by screening tests or neurological examination. Milestones are certain behaviors and skills that are important for each developmental age and were obtained by observing and monitoring mental and motor development in a large number of children. The most commonly used milestones were first smile to the mother, self-seating, first words, independent walking, etc., and data on the age of their occurrence are usually given by parents according to their memory. International literature data yield a multitude of screening tests such as Ages and Stages Questionnaire (ASQ), Kent Inventory of Developmental Skills (KIDS), Denver Developmental Screening Test II (DDST-II), Bayley Infant Neurodevelopmental Screener (BINS), Early Screening Inventory-Revised (ESI-4), and others ${ }^{1}$. Screening tests in- 
volve the use of toys, ball, pens, paper, or other materials to display the child's skills and behaviors.

In Croatia, a screening test for rough estimate of psychomotor development in full term children in the first two years of life (Croatian, Razvoj psibomotorike, RPM test) was constructed by Nevenka Čuturić, psychologist, in $1976^{2}$. At the time, physiatrists did not participate in the creation of that test.

Optimal mental and physical development is equally important for subsequent independent life. While physical development can be measured by body height, body weight, head circumference, etc., there is no instrument to measure mental development of the child at an early age, and it is assessed and monitored via appearance of specific activities. Prechtl and co- $^{-}$ workers have developed a technique based on the quality of general movements, estimated by video observation, as a diagnostic tool for early detection of brain dysfunction ${ }^{3,4}$. General movements include complex movement forms of the head, trunk, arms and legs, which predict neurological outcome over 2 years, especially in children with cerebral palsy ${ }^{5}$. These movements can be observed in fetuses from the $9^{\text {th }}$ week of gestational age until the end of the second month post term $^{6}$. Normal general movements involve the whole body and may last from a few seconds to a few minutes or even longer. They have their trajectories, intensity, force, speed, gradual beginning and end, and when some components like flexion, extension or rotations are added, they become fluent and elegant with impression of complexity and variability ${ }^{3}$. During term and first post term age, general movements are characterized by slow to moderate amplitude and speed, being elliptical in form and with the impression of a writhing character and therefore are called writhing movements ${ }^{7}$. There are 3 types of general movements in children described during preterm, term and in the first 2 months post term:

1) poor repertoire of general movements - monotonous movements, movements of different body parts do not appear in the complex way as seen in normal general movements ${ }^{8,9}$;

2) cramped - synchronized general movements rigid movements with lack of normal smooth and fluent character, limb and trunk muscles contract and relax almost simultaneously ${ }^{8,9}$; and

3) chaotic general movements - large amplitude of movements of all limbs, and appear in chaotic order without any fluency or smoothness ${ }^{10}$.
General movements of normal infants from 6 to 9 weeks post term change from writhing to fidgety movements, which are characterized by circular movements of small amplitude, moderate speed and variable acceleration in all directions ${ }^{4}$. Fidgety movements can be characterized as absent if never observed from 6 to 20 weeks post term, or abnormal if their amplitude, speed and jerkiness are exaggerated ${ }^{9}$.

General movements usually disappear at the age of 3 to 4 months post term and after that the quality of spontaneous movement is judged by standard neurological examination. Apart from the quality of general movements, standard neurological examination from the birth might be used, but some studies showed that general movement observation had better sensitivity and specificity values than neurological examination as a prognostic value for the neurological outcome within 2 years $^{11}$.

Infantile neurological functions from 6 weeks to 4.5 months post term are visual orientation, fixing and following objects, and reaction to sound, vocalization, smile and interaction with familiar person. During this period, most of the primitive reflexes disappear and postural reactions occur such as head control and active flexion of upper and lower limbs, while hand is preparing for catching. In the period from 5 to 12 months post term, neurological functions are goal directed voluntary catching, radio palmar and pincers grasp, and transferring toys from one hand to another. Postural control and sliding position are developed such as support to the extended arm, open palms, position on all fours, sitting, kneeling, crawling, standing and rotating. Then, communication and speech develop, i.e. first meaningful syllables, imitation of familiar syllables, recognizing familiar persons, and performing simple tasks, e.g., come here, give me, leave it, etc. ${ }^{12}$.

At the beginning of the second year, most children walk independently, initially on a large scale and later walk becomes more agile. At 18 months, most children can climb the stairs one by one, and at 20 months going the same way downstairs, jumping with both feet and throwing the ball. At the time, children are familiar with parts of the body, compose simple sentences and begin to express needs, imitate their parents and strive for the greatest possible independence.

It is extremely important to know the normal mental and motor development of the child in order to determine deviations that can range from mild such as 
slow development to extremely severe such as cerebral palsy or mental retardation. Serious discrepancies already manifest in infancy, while milder ones usually manifest after the first year ${ }^{13}$. Brain plasticity is a unique neurobiological process limited to the perinatal period and infancy, and it is assumed that neurodevelopmental outcome after perinatal damage depends on the interaction of the existing brain damage and compensation process of maturation and brain plasticity ${ }^{14,15}$. Timely detection of developmental deviations and application of rehabilitation procedures can stimulate the processes of brain plasticity and contribute to recovery of the damaged function ${ }^{15,16}$.

The aim of this study was to determine whether there is difference in the assessment of psychomotor development in neurological risk children between the test assessing psychomotor development (RPM test) and clinical evaluation of neuromotor development by the child's physiatrist, as well as to compare the RPM test results between the neurological risk and healthy children with no known neurological risk factors and deviations from normal psychomotor development.

\section{Patients and Methods}

This pilot study conducted from January 2015 to June 2016 included 30 full term (38-42 weeks) children (16 male and 14 female) aged 12 to 24 months. The first group of 15 children had undergone some form of rehabilitation at the Department of Pediatric Rehabilitation, University Department of Rheumatology, Physical Medicine and Rehabilitation, Sestre milosrdnice University Hospital Center, Zagreb, because they had deviations from normal psychomotor development. All these children started rehabilitation before the $4^{\text {th }}$ month of life and all had cranial ultrasound abnormalities and intraventricular hemorrhage stage I or II. Therefore, they were classified as children with low neurological risk. Besides ultrasound findings, deviations from normal psychomotor development such as mild abnormalities were identified by the child physiatrist examination consisting of Prechtl's method and classical neurological examination, neuropediatrician and psychologist examination. All these children are now at the age of 12-24 months and have a diagnosis of mild paraparesis. These children also have some impairment of psychological or social develop- ment and have been regularly followed-up by speech therapist at the Department.

The following questionnaires were used: RPM questionnaire (50 items) - rough estimate of the psychomotor development of full term children in the first two years of life; monograph of psychomotor development in the first two years of life $^{2}$; and instructions for performing and scoring RPM screening test. RPM test is performed by physiatrists and nurses employed at the Department of Pediatric Rehabilitation, Clinical Department of Rheumatology, previously trained in proper performance of the test. To conduct the RPM test we used rattle, paper napkins, cubes, mug, pen and paper, picture book, and ball. After being used, all these objects are cleaned with medical alcohol and a clean paper napkin is used in each child. Testing is always performed by the same procedure for a particular age with the manual and questionnaire. During the test, the mother was always present with the child and there was no other person in the room except for the mother, the child and the examiner. Prior to testing, mothers were familiarized with the protocol but not with the ultimate goal of the study. The testing started upon the mother's agreement for participation. The research was conducted in accordance with ethical principles.

Inclusion criteria for the study were chronological age of full term (38-42 weeks) children aged 12 to 24 months; cranial ultrasound abnormalities such as intraventricular hemorrhage stage I or II; diagnosis of mild paraparesis; and some impairment of psychological or social development. All study children were free from serious disease in the last two weeks (fever, and respiratory or gastrointestinal system infections). On the day of testing, the child was not exposed to any other preventive examinations, weight measuring or vaccination. Children who did not meet the above criteria were not included in the study.

General information about the child and the parents were given by the mother. Then, testing using the RPM questionnaire was done. This questionnaire includes 7 units of milestones and 24 units related to rough estimate of psychomotor development and grouped according to the child's chronological age of 3-24 months. According to the child's chronological age $3,6,9,12,18$ or 24 months, there are 6 groups, each containing four items pertaining to the child's behavior. Each item is scored with a '+', '+/-' or '-' on 
the basis of behavior the child shows during the test. Three additional items within each group include questions to the mother. We were focused on the three groups corresponding to chronological age of the examined child (12 to 24 months). At the end of the questionnaire is a group of questions related to milestones according to which the mother can determine the age when she first noticed the child's specific behavior. Regardless of the chronological age of the child, items 1 and 2 examine development of motor skills, 3 and 4 development of sensorimotor skills, 5 and 6 development of cooperation with the environment, and item 7 development of speech.

Individual child's behavior was marked by ' + ', behavior uncertain by '+/- ', and non-existing behavior by '- '. We marked only one answer for a particular behavior.

After the testing had been completed we added up all signs in the provided space. Rough estimate of the development, based on the results for a given chronological age, is classified into 3 groups:

1) good (D) - the child shows most behaviors for a particular age, or has 4 or more behaviors marked by '+'. Two uncertain behaviors marked by '+/-' are marked by ' + ';

2) suspect $(\mathrm{S})$ - the child has 2 or 3 behaviors marked by ' + 'or 2 behaviors ' + ' and 2 behaviors '+/-' or 7 uncertain behaviors '+/-'; and

3) slow $(U)$ - the child has one or none behavior marked by ' + '.

Mother's answers to questions from the group called milestones are recorded in the form of months when the mother first noticed a particular child's behavior. These responses were compared with the timeframe occurrence of a particular behavior in the majority and in all children (frames of child's age for a particular behavior are listed in the instructions).

The second, control, group of 15 full term children aged 12-24 months included children with no known neurological risk factors and deviations from normal psychomotor development. These children were tested by pediatricians at pediatric clinic of the Pakrac Health Center, in the same manner as described for the first group children and using the same RPM screening test.

Statistical analysis based on descriptive statistics, frequencies and percentages was performed by use of the Statistical Package for Social Sciences 13.0 (SPSS 13.0).

\section{Results}

Based on the RPM screening test, out of the 15 children diagnosed with mild paraparesis and some impairment of psychological or social development, only one (6.7\%) child had suspect (S) result and 14 (93.3\%) children had good results (D). All control group children with no deviations from normal psychomotor development had good result (D) (Fig. 1).

Detailed analysis of the RPM questionnaire for the children diagnosed with mild paraparesis by the items ranging from 1 to 7 or 4 groups of behavior (motor skills -2 , sensorimotor skills -2 , cooperation with the environment - 2 and speech - 1) showed some deviations from normal development, although the overall result for 14 of 15 children was good. In this group of 15 children, $13.3 \%$ had some deviations in motor skills, $20 \%$ in sensorimotor skills, $6.7 \%$ in cooperation with the environment and $13.3 \%$ in speech. Analysis of the control group children revealed no abnormalities (Fig. 2).

In the end, the two groups were compared according to the number of deviations from the proper framework of milestones. Excellent result (no deviations) was recorded in only $6.7 \%$ of children with mild paraparesis versus $33.3 \%$ of children without deviations from normal psychomotor development. One to three deviations had $66.7 \%$ of children with mild paraparesis and $53.3 \%$ of children with no deviations from normal psychomotor development. Four and more deviations had $26.7 \%$ of children with mild paraparesis

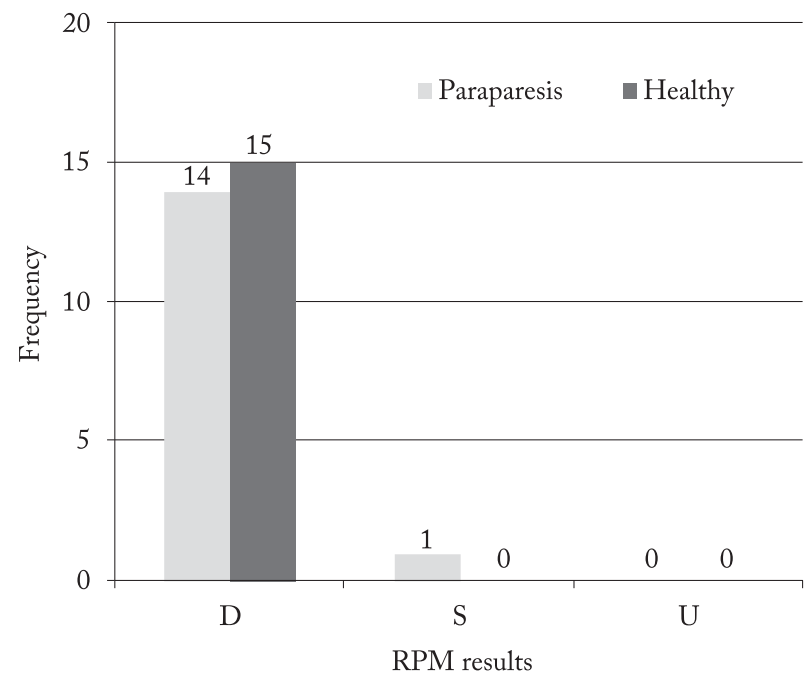

Fig. 1. Comparison of RPM test results between the two groups of children. 


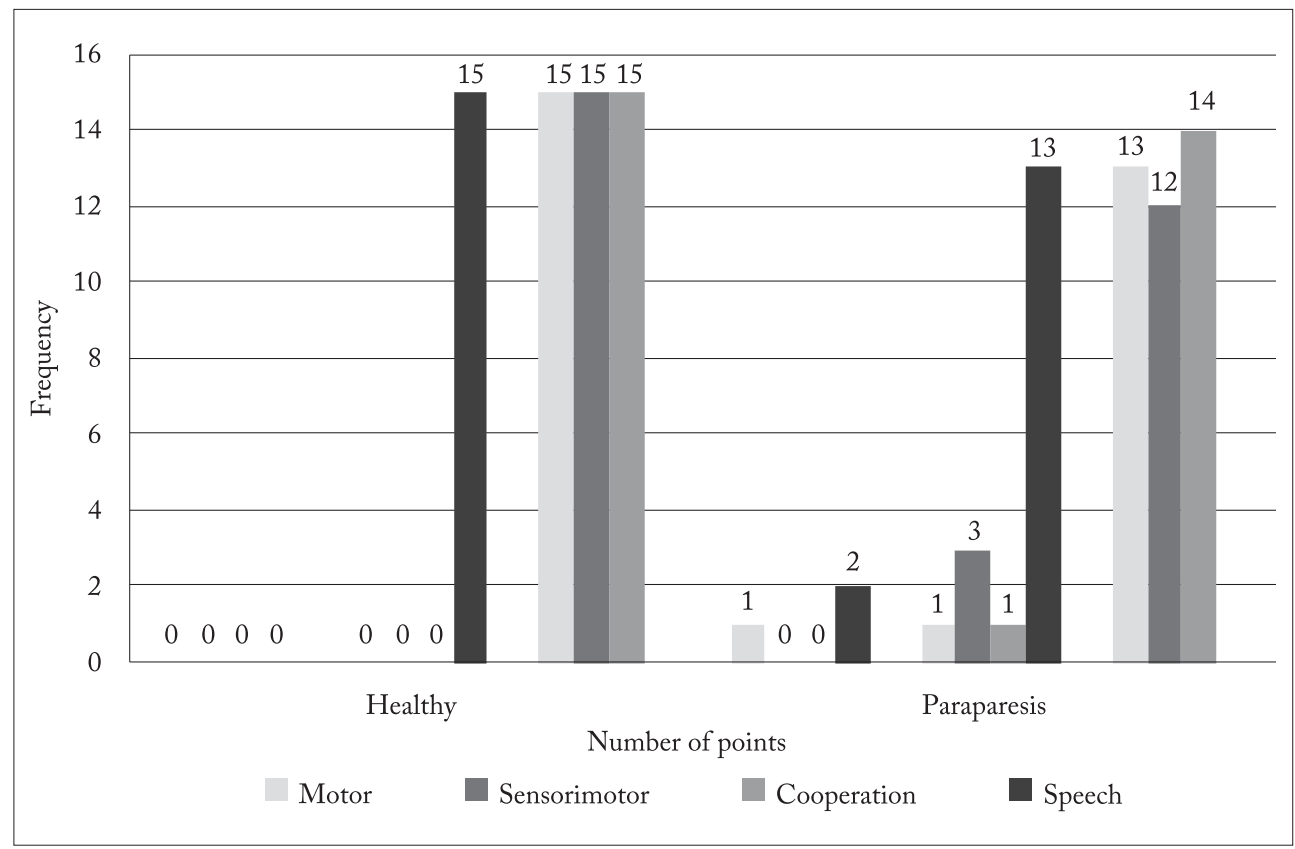

Fig. 2. Comparison of detailed analysis of RPM questionnaires between the two groups of children.

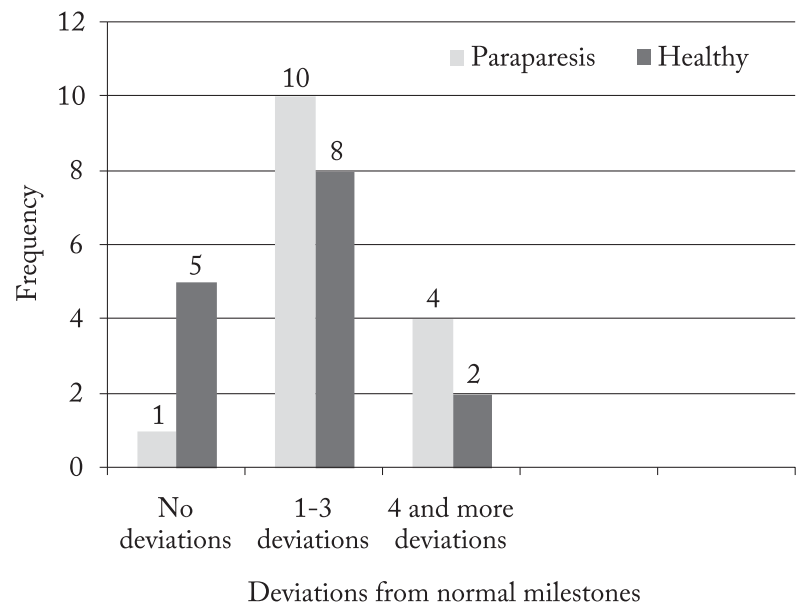

Fig. 3. Comparison of the two groups of children according to the number of deviations from the proper framework of milestones.

and $13.3 \%$ of children with no deviations from normal psychomotor development (Fig. 3).

\section{Discussion}

Numerous studies show that $10 \%-15 \%$ of live born babies belong to the group of children with neurologi- cal risk. Eighty percent of these children show normal development, whereas twenty percent exhibit short- or long-term disabilities manifested in the early childhood $^{17}$. Early detection and monitoring of children with neurological risk is one of the longest applied methods for the detection of neurodevelopmental disorders in children. Children with neurological risk can be divided into two groups with high and low neurological risk. This division is based on the criteria such as the number of risk factors in medical history, clinical risk factors, and findings of intracranial ultrasound. Abnormal pregnancies and deliveries are frequent causes of prematurity, perinatal asphyxia and birth trauma with intracranial hemorrhage that can lead to various degrees of brain damage and subsequent developmental disorders ${ }^{18}$. Children with high neurological risk have more than two risk factors in medical history, with clinical risk factors such as the syndrome of irritation, apathy, spasticity or dystonia, clearly abnormal general movements, premature infants with cystic periventricular leukomalacia, full-term infants with subcortical leukomalacia, infants with intraventricular hemorrhage stage IV and complicated stage III, or infants with perinatal infarction. Children with low neurological risk have less than two risk factors in medical 
history, with the syndrome of dystonia, mild abnormal general movements, and infants with ultrasound findings of uncomplicated hemorrhage, subependymal hemorrhage, and intraventricular hemorrhage stage I to $\mathrm{III}^{19}$. Neurological monitoring of children after the age of two years showed that $70 \%$ of children from the group with high neurological risk had serious neurological consequences and $10 \%$ of children from the group with low neurological risk had mild neurodevelopmental disorders ${ }^{20}$.

Clinical evaluation that includes classical neurological examination and examination by Prechtl (based on the evaluation of the quality of general movements) is a method that allows early detection of children with neurodevelopmental disorders.

The RPM questionnaire, known in Croatia as a screening test for full-term children in the first two years of life, was designed as a screening test for rough estimate of psychomotor development of these children. Its purpose is to help healthcare professionals timely respond with appropriate therapy in children with deviations from normal psychomotor development. This screening test or method of evaluation involves the use of different objects such as toys, picture books, pens, etc., so that the child can show particular behavior or skill. The staff conducting the screening test should be educated and the test should be always carried out in the presence of parents. Screening test is not a diagnostic instrument but a tool designed to roughly sort out children that need further psychological and medical treatment.

As in the present study, the RPM test performed in children diagnosed with mild paraparesis showed only one suspect result (S) and 14 good results (D), it seems that it is not sensitive enough to detect mild neurodevelopmental disorders. However, when detailed analysis of the RPM questionnaire between the two groups of children was performed, the test showed discrepancies in the results between the children with mild paraparesis and those with no deviations from normal psychomotor development.

\section{Conclusion}

Based on our results, the RPM test is not sensitive enough to detect mild neurodevelopmental disorders when final results were calculated, but some could have been detected upon detailed analysis. Both severe and mild deviations from normal psychomotor development are conditions that require early detection and early inclusion in the rehabilitation process, which can speed up recovery and minimize damage owing to brain plasticity. However, it is advisable to use all tools and methods available to detect deviations as early as possible and to rehabilitate the child successfully. And the last but not the least, we need a new tool to assess neuromotor development, developed by educated experts such as child physiatrists, so as not to overlook the smallest deviations from normal neuromotor development.

\section{References}

1. Ringwalt S. Developmental Screening and Assessment Instruments with an Emphasis on Social and Emotional Development for Young Children Ages Birth through Five. National Early Childhood Technical Assistance Center (NECTAC). 2008; http://www.nectac.org/ pdfs/pubs/screening.pdf

2. Čuturić N. Psihomotorički razvoj djeteta u prve dvije godine života: s normama razvoja. Jastrebarsko: Naklada Slap; 2001. (in Croatian)

3. Prechtl HF. Qualitative changes of spontaneous movements in fetus and preterm infant are a marker of neurological dysfunction. Early Hum Dev. 1990;23(3):151-8.

4. Einspieler C, Prechtl HF, Ferrari F, Cioni G, Bos AF. The qualitative assessment of general movements in preterm, term and young infants - review of the methodology. Early Hum Dev. 1997;50(1):47-60.

5. Prechtl HF. State of the art of a new functional assessment of the young nervous system. An early predictor of cerebral palsy. Early Hum Dev. 1997;50(1):1-11.

6. De Vries JI, Visser GH, Prechtl HF. The emergence of fetal behaviour. I. Qualitative aspects. Early Hum Dev. 1982;7(4):301-22.

7. Prechtl HF, Hopkins B. Developmental transformations of spontaneous movements in early infancy. Early Hum Dev. 1986;14(3):233-8.

8. Ferrari F, Cioni G, Prechtl HF. Qualitative changes of general movements in preterm infants with brain lesions. Early Hum Dev. 1990;23(3):193-231.

9. Prechtl HF, Einspieler C, Cioni G, Bos AF, Ferrari F, Sontheimer D. An early marker for neurological deficits after perinatal brain lesions. Lancet. 1997;349(9062):1361-3.

10. Bos AF, van Loon AJ, Hadders-Algra M, Martijn A, Okken A, Prechtl HF. Spontaneous motility in preterm, small-for gestational age infants. II. Qualitative aspects. Early Hum Dev. 1997;50(1):131-47.

11. Cioni G, Prechtl HF, Ferrari F, Paolicelli PB, Einspieler C, Roversi MF. Which better predicts later outcome in full term infants: quality of general movements or neurological examination? Early Hum Dev. 1997;50(1):71-85. 
12. Mejaški-Bošnjak V. Rani neurološki razvoj djeteta. Paediatr Croat. 2008;52(1):36-42. (in Croatian)

13. Amiel-Tison C, Ellison P. Birth asphyxia in the full term newborn: early assessment and outcome. Dev Med Child Neurol. 1986;28(5):671-82.

14. Kostović I, Judaš M. Transient patterns of organization of the human fetal brain. Croatian Med J. 1998;39(2):107-14.

15. Mejaški-Bošnjak V. Dijagnostički pristup ranom otkrivanju neurorazvojnih odstupanja. Peadiatr Croat. 2007;51:105-10. (in Croatian)

16. Mejaški-Bošnjak V. Neurološki sindromi dojenačke dobi i cerebralna paraliza. Paediatr Croat. 2007;51(Suppl 1):120-9. (in Croatian)
17. Matijević Mikelić V, Košiček T, Crnković M, Radanović B. Participation of Mchildren with neurodevelopmental risk factors in the early rehabilitation program in relation to the level of parental education. Acta Clin Croat. 2011;50(4):457-60.

18. Mustafić N, Trnovčević J. Neurorizično dijete. Pedijatrija Danas. 2006;2:54-6. (in Croatian)

19. Crnković M, Matijević-Mikelić V, Demarin V, Košiček T, Morović S, Grazio S. Risk factors for gross motor dysfunction of lower limbs in children. Acta Clin Croat. 2011;50(2):361-6.

20. Bošnjak-Nađ K, Mejaški-Bošnjak $V$, Popović-Miočinović Lj, Kapitanović Vidak H, Grubešić Z, Sremić Š. Prepoznavanje i praćenje neurorizičnog djeteta. Paediatr Croat. 2004;48(Suppl 1):55. (in Croatian)

\section{Sažetak}

\section{USPOREDBA PROBIRNOG TESTA RAZVOJ PSIHOMOTORIKE I KLINIČKE PROCJENE PSIHOMOTORNOG RAZVOJA}

\section{G. Radmilović, V. Matijević i I. Zavoreo}

Mnoštvo je nepovoljnih čimbenika koji djeluju u prenatalnom, perinatalnom i postnatalnom razdoblju života, a mogu biti uzrokom kasnijih blažih ili težih odstupanja od normalnog psihomotornog razvoja. Stoga je od presudne važnosti identificirati dojenčad s neurorizičnim čimbenicima i dojenčad u koje već postoji odstupanje od urednog neuromotornog razvoja kako bi ih se odmah uključilo u rehabilitacijski proces. Cilj ove studije bio je utvrditi postoji li razlika u procjeni psihomotornog razvoja neurorizične djece na temelju testa Razvoj psihomotorike (test RPM) i kliničke procjene neuromotornog razvoja. Test RPM je namijenjen za grubu procjenu psihomotornog razvoja donešene djece u prve dvije godine života. U studiju je bilo uključeno 15 donešene djece (8 muških, 7 ženskih) s kliničkom dijagnozom diskretne parapareze te blagim odstupanjem od normalnog psihološkog ili socijalnog razvoja i 15 donešene djece ( 8 muških, 7 ženskih) bez neurorizičnih čimbenika $i$ odstupanja od normalnog psihomotornog razvoja, a svi u dobi od 12-24 mjeseca. Od 15 djece s dijagnozom diskretne parapareze niti jedno dijete prema testu RPM nije imalo usporen razvoj, 6,7\% je imalo sumnjiv razvoj, dok je u 93,3\% razvoj bio uredan. Sva djeca u kontrolnoj skupini su prema testu RPM imala uredan razvoj. Prema dobivenim rezultatima test RPM nije dovoljno osjetljiv da bi otkrio blage neurorazvojne poremećaje.

Ključne riječi: Dijete; Razvojni poremećaji; Psihomotorni poreméaji; Rebabilitacija 